\title{
RANCANGAN DASHBOARD KINERJA LAYANAN PASIEN RUMAH SAKIT
}

\author{
Agus Prasetyo Utomo ${ }^{1}$, Novita Mariana ${ }^{2}$, Rara Sri Artati Rejeki ${ }^{3}$ \\ 1,2,3Program Studi Sistem Informasi, Fakultas Teknologi Informasi, Universitas Stikubank \\ e-mail : ${ }^{1}$ mustagus@edu.unisbank.ac.id, ${ }^{2}$ h4n4.473ng@gmail.com, ${ }^{3}$ rara_artati@yahoo.com
}

\begin{abstract}
Abstrak
Manajemen rumah sakit perlu melakukan monitoring dan pengukuran secara terusmenerus terhadap kinerja layanan pasien untuk memastikan ketercapaian tujuan yang telah ditetapkan. Proses monitoring kinerja memerlukan data dan informasi yang didapatkan dari umpan balik pasien terhadap layanan dokter dan perawat. Hasil monitoring kinerja selanjutnya akan disampaikan kepada pihak-pihak yang berkepentingan, secara efisien dan efektif. Performance Dashboard merupakan alat untuk menyajikan informasi secara sekilas . Dashboard menginformasikan Key Performance Indicators (KPI) dengan menggunakan media penyajian yang efektif. KPI yang digunakan dalam pembangunan Dasboard adalah kuesioner tingkat kepuasan layanan pasien terhadap dokter dan perawat. Penelitian ini lebih menitikberatkan bagaimana rancangan dashboard ini bisa memberikan kemudahan informasi terhadap manajemen rumah sakit untuk memonitor dan mengevaluasi capaian kinerja layanan pasien.
\end{abstract}

Kata kunci : Perancangan, Dashboard, Key Performance Indikator, Kinerja Rumah Sakit.

\section{PENDAhuluan}

Kinerja layanan kepada pasien merupakan salah satu dimensi utama dari mutu pelayanan rumah sakit (Katz \& Green, 1997). Diperlukan indikator-indikator layanan terhadap pasien untuk menilai kinerja layanan rumah sakit, indikator kinerja yang terbentuk tidak hanya berupa indikator finansial (keuangan) tetapi juga indikator nonfinansial terutama untuk mengukur outcome. Proses evaluasi mutu pelayanan RS dilakukan melalui sistem akreditasi rumah sakit. Melalui akreditasi, rumah sakit dapat mengevaluasi peningkatan mutu, gambaran tentang baik tidaknya kinerja personil rumah sakit dalam melaksanakan tugasnya.

Setiap organisasi perlu melakukan monitoring dan pengukuran kinerja secara terus-menerus untuk memastikan strategi pengelolaan yang tepat. Pengukuran kondisi organisasi memerlukan data dan informasi dari seluruh bagian yang merupakan hasil dari proses Business Intelligence (BI) yang akan dijadikan dasar pengambilan keputusan.

Pengelolaan dan penyajian informasi bukanlah hal yang mudah, mengingat kompleksitas dan banyaknya informasi yang dimiliki organisasi. Organisasi memerlukan sebuah 'tool' untuk mengelola informasi dan menyajikannya dalam bentuk yang efisien dan efektif, yakni dashboard. Dashboard merupakan alat untuk menyajikan informasi secara sekilas, solusi bagi kebutuhan informasi organisasi (Few, Stephen. 2006). Dashboard memberikan tampilan antarmuka dengan berbagai bentuk seperti diagram, laporan, indikator visual, mekanisme alert, yang dipadukan dengan informasi yang dinamis dan relevan (Golfarrelli, M. 2005). Dashboard mengumpulkan informasi yang relevan dari berbagai bagian organisasi, mengkonsolidasikan, dan menyampaikannya secara aman, cepat, dengan personalisasi sesuai dengan peran pengguna dalam organisasi (Negash, S; \& Gray,P.2003)

Untuk penyajian informasi yang berhubungan dengan pengukuran kinerja biasanya pihak Rumah Sakit masih menggunakan cara manual dengan mempersiapkan serta menyusun laporan yang berkaitan dengan kinerja RS tersebut dan membutuhkan waktu, tenaga yang tidak sedikit. Hal ini juga dapat mempengaruhi proses monitoring kinerja dari RS tersebut dikarenakan keterlambatan informasi yang dibutuhkan.

Penerapan performance dashboard diharapkan dapat memudahkan dalam pengukuran kinerja Rumah Sakit untuk membantu pemantauan dan pengendalian kegiatannya dengan memberikan informasi yang berkualitas. Upaya memaksimalkan kinerja organisasi dan yang jelas organisasi 
mampu mengidentifikasikan, menjelaskan, dan mengimplementasikan strateginya akan mampu berkembang dan berkompetisi lebih baik.

\subsection{Perumusan Masalah dan Pembatasan Masalah}

Dari latar belakang masalah maka perumusaan masalahnya adalah bagaimana merancang dashboard yang digunakan untuk mengukur kinerja layanan pasien rumah sakit.

Agar pembahasan dalam penelitian ini tidak terlalu melebar dan sesuai dengan tujuan penelitian yang hendak dilakukan, maka perlu dilakukannya pembatasan masalah. Penulis membatasi masalah yang akan diteliti. Adapun pembatasan masalah yang akan diteliti adalah sebagai berikut :

1. Perancangan dashboard kinerja layanan rumah sakit ini hanya sampai pada tahap modeling saja dan akan diuji dengan menggunakan model simulasi.

2. Solusi yang diberikan berupa informasi kinerja layanan rumah sakit yang ditujukan untuk kepentingan manajemen dalam memonitor kinerja layanan pasien yang dilakukan oleh dokter dan perawat.

\subsection{Tujuan dan Manfaat Penelitian}

Tujuan dalam penyusunan penelitian ini adalah merancang sistem manajemen kinerja layanan pasien rumah sakit untuk menghasilkan suatu sistem informai yang dapat memberikan kemudahan bagi manajemen rumah sakit dalam memonitor kinerja organisasinya. Sementara itu manfaat yang diperoleh dari penelitian ini dapat memberikan gambaran kepada manajemen terkait dengan capaiancapaian kinerja layanan pasien rumah sakit yang sudah direncanakan.

\subsection{Tinjauan Pustaka}

Golfarrelli, M. (2005) melakukan penelitian bahwa perusahaan saat ini lebih berorientasi proses daripada di masa lalu, bahkan, untuk mengurangi biaya dan mengikuti pasar, mereka mengadopsi strategi end-to-end yang melibatkan kedua pelanggan dan pemasok untuk menyinkronkan semua kegiatan usaha. Pada saat yang sama, perusahaan harus memahami pentingnya menegakkan pencapaian tujuan ditentukan oleh strategi mereka melalui metrik-driven manajemen. Menerjemahkan strategi perusahaan kedalam seperangkat indikator yang lebih dekat dengan tugas operasional memungkinkan karyawan untuk lebih memahami keinginan manajer. Proses Datawarehouse hanya mencakup bagian dari kerangka kerja ini, bahkan, pada dasarnya membantu manajer untuk memahami perusahaan mereka dengan mendukung bottom-up ekstraksi informasi dari data, sehingga kurang dalam melaksanakan strategi perusahaan secara top-down. Menjembatani kesenjangan ini menandai titik balik dalam sejarah BI, yang tidak lagi dianggap sebagai seperangkat teknik untuk ekstraksi informasi dan pengolahan, tetapi juga sebagai pendekatan aktif dan konkret untuk manajemen bisnis yankni dengan pemanfaatan BPM, yang dapat didefinisikan sebagai serangkaian proses yang membantu organisasi bisnis mengoptimalkan kinerja dengan mendorong proses efektivitas serta efisiensi penggunaan sumber daya manusia, keuangan, dan material.

Mihaela I. Muntean, Diana-Alexandra Tarnaveanu, dan Anca Paul menjelaskan Salah satu solusi bisnis yang dapat digunakan adalah Business Performance Management. BPM merupakan solusi bisnis berorientasi untuk memasok hasil termasuk informasi tentang kegiatan dari manajer operasional sampai manajer top. Proses ini didesain agar dapat membantu mengoptimalkan pengukuran bisnis. Salah satu pengukuran yang digunakan adalah Balanced Scorecard, yakni pengukuran kinerja berdasarkan visi dan misi. Salah satu aplikasi BI yang diteliti oleh peneliti adalah untuk memonitor web-traffic yang memiliki beberapa fungsi yakni memonitor pengunjung website, memonitor website yang diakses oleh pengunjung. Penyebaran pengunjung berdasarkan geografi, total jumlah pengunjung, rata-rata lama akses pengguna website, penyebaran website yang dihubungkan dengan search-engine yang digunakan. Untuk mendukung BI tersebut dikombinasikan dengan teknik performance management yakni balanced scorecard untuk meningkatkan kompentensi.

Tobias Mettler dan Vivian Vimarlund (2008) melakukan penelitian tentang penerapan teknologi informasi dalam perawatan kesehatan saat ini dilihat sebagai kesempatan untuk meningkatkan tidak hanya efektifitas, efisiensi, dan kualitas pelayanan kesehatan tetapi juga ketersediaan informasi secara 
real time. Sehingga dibutuhkan Business Intelligence pada sektor kesehatan untuk pengumpulan kinerja yang sistematis. Juga peningkatan persaingan di sektor tersebut akan mendorong penyebaran dari luas berbagai informasi yang berkaitan dengan pelayanan kesehatan.

John Starmer dan Dario Giuse (2008) merancang dan menerapkan dashboard manajemen ventilator yang memiliki tujuan yang pertama adalah untuk menyediakan up-to-the-minute status untuk setiap ventilasi pasien, untuk membantu koreksi secara real-time. Tujuan kedua adalah terus menerus memonitor status berkelanjutan, untuk membantu identifikasi hambatan melalui harian, mingguan dan laporan status bulanan. Untuk setiap elemen, indikator yang ditampilkan akan menunjukkan status dengan skema sederhana warna merah, kuning, dan hijau. Peneliti merancang dashboard sesuai arsitektur yakni diawali mengambil data dari berbagai sumber sistem yang telah di gunakan oleh personel klinis, termasuk sistem dokumentasi klinis dan CPOE. Selanjutnya data-data tadi dimasukkan melalui mesin antarmuka yang disebut EMR, data yang relevan akan dijadikan indikator dashboard. Sebuah lapisan aturan bisnis berlaku untuk menentukan warna dan status yang akan ditampilkan pada klinis dashboard. Tampilan dashboard tersedia baik dalam ESDM, dan juga sebagai screen saver pada masing-masing workstation di semua ICU. Screen saver sudah dikonfigurasikan sebelumnya untuk menampilkan status untuk setiap pasien dalam ICU tertentu.

Andy Koronios dan Jing Gao (2010) meneliti dashboard sebagai alat BI sering dianggap sebagai alat yang berguna untuk memonitor kinerja organisasi/departemen. Kinerja dapat diukur melalui kinerja utama indikator (KPI). KPI sangat penting untuk manajemen pengambilan keputusan dan digunakan oleh semua tingkat organisasi untuk mengukur tingkat keberhasilan.

Information dashboard adalah tampilan visual dari informasi penting, yang diperlukan untuk mencapai satu atau beberapa tujuan, dengan mengkonsolidasikan dan mengatur informasi dalam satu layar (single screen), sehingga kinerja organisasi dapat dimonitor secara sekilas. Tampilan visual disini mengandung pengertian bahwa penyajian informasi harus dirancang sebaik mungkin, sehingga mata manusia dapat menangkap informasi secara cepat dan otak manusia dapat memahami maknanya secara benar (Few, 2006).

Dashboard yang didefinisikan sebagai mekanisme penyajian informasi secara visual di dalam sistem manajemen kinerja, yang menyajikan informasi kritis mengenai kinerja proses operasional secara sekilas. Penggunaan Dashboard menitikberatkan untuk monitoring kinerja dari proses operasional (Eckerson, 2005).

Berdasarkan penjelasan-penjelasan tersebut, dapat dinyatakan bahwa istilah enterprise dashboard, information dashboard, dan dashboard memiliki pengertian yang sama, yaitu sebuah alat yang memberikan tampilan antar muka visual, yang mengkonsolidasikan dan menyajikan informasi penting yang diperlukan untuk mencapai tujuan tertentu, secara sekilas dalam satu layar(single screen). Tujuan penggunaan dashboard mirip dengan dashboard yang terdapat pada pesawat, yaitu untuk memonitor dan mengarahkan sebuah sistem yang kompleks dan interdependent. Organisasi diibaratkan seperti sebuah pesawat. pada saat mengoperasikan pesawat, pilot memerlukan informasi mengenai kondisi pesawat, baik internal maupun eksternal. Informasi tersebut digunakan untuk membuat keputusan mengenai hal-hal yang harus dilakukan oleh pilot dalam mengoperasikan pesawat, agar berhasil sampai pada tujuan yang ditentukan dalam kondisi baik (Malik, 2005).

Dashboard didesain untuk membantu organisasi dalam mencapai tujuan strategisnya. Dashboard digunakan untuk mengukur proses yang telah berjalan, memonitor kinerja yang sedang berjalan, dan memprediksi kinerja di masa mendatang. Dengan melakukan hal tersebut, organisasi dapat membuat, menilai, menyesuaikan, dan menyusun kembali strategi yang telah dibuat untuk mengoptimalkan kinerjanya (Eckerson, 2005).

\subsection{Pengukuran Kinerja}

Pengukuran kinerja dalam suatu perusahaan sangat penting untuk dilakukan, karena dengan pengukuran tersebut kita dapat mengetahui apa yang kita dapatkan melalui sesuatu yang terukur. Apa yang diukur biasanya mendapatkan perhatian. Yang lebih penting adalah jika kita tidak dapat mengukur suatu hal, maka akan sulit untuk dapat mengelolanya. Dalam kerangka pikir inilah dapat 
dinyatakan bahwa pengukuran kinerja menjadi sebuah alat untuk mengkaji ulang manajemen stratejik yang diterapkan oleh pihak manajemen.

Pengukuran terjadi jika suatu alat ukur tertentu dipakai untuk memastikan, berat, tinggi atau ciri lain dari suatu obyek yang sedang diukur. Dalam kehidupan sehari-hari kita sering melakukan pengukuran, namun dalam penelitian, untuk melakukan pengukuran harus memenuhi syarat-syarat tertentu. Pengukuran dalam penelitian terdiri dari pemberian angka-angka pada peristiwa empiris sesuai dengan aturan-aturan tertentu (Cooper dkk, 1996).

Dalam pengukuran kita membentuk suatu skala dan kemudian mentransfer pengamatan terhadap ciri-ciri kepada skala tersebut. Ada berbagai kemungkinan skala; pilihan yang sesuai tergantung kepada anggapan peneliti engenai aturan pemetaan. Setiap skala mempunyai himpunan asumsi masing-masing yang melatar belakangi hubungan angka-angka dengan praktek sehari-hari. Pengelompokkan skala memakai sistem bilangan nyata. Dasar yang paling umum menurut untuk membuat skala mempunyai tiga ciri (Cooper dkk, 1996):

1. Bilangan berurutan

2. Selisih antara bilangan-bilangan berurutan

3. Deret bilangan mempunyai asal mula yang unik yang ditandai dengan bilangan nol.

Pengelompokkan skala ukuran dapat dilihat pada tabel 2.1.

Dalam perancangan suatu sistem manajemen kinerja terdapat 4 tahap dalam perancangan sistem manajemen kinerja, (Wibisono, 2006):

a. Tahap 0 : Fondasi

Pemahaman atas pedoman prinsip yang harus dijadikan fondasi bagi rancangan sistem manajemen kinerja.

b. Tahap 1 : Informasi Dasar

Informasi dasar yang diperlukan sebagai masukan bagi perancang sistem manajemen kinerja pada dasarnya menyangkut lingkungan usaha yang saat ini sedang digeluti, yang terdiridari informasi tentang industri, pemerintah dan masyarakat, pasar dan pesaing, serta produk dan jasa yang dihasilkan perusahaan.

c. Tahap 2 : Perancangan

Merupakan lankah perancangan sistem manajemen kinerja yang terdiridari penentuan visi, misi, strategi, dan kerangka kerja yang digunakan sebagai dasar penentuan variabel kinerja, keterkaitan antar variabel, dan kaji banding (bencmark) yang akan diambil.

d. Tahap 3: Penerapan

Merupakan tahap penerapan rancangan yang meliputi display yang akan didukung, laporan yang akan dirancang, sosialisasi sistem manajemen kinerja kepada seluruh karyawan, analisis manfaat/biaya bagi penerapan sistem manajemen kinerja, modifikasi proses yang diperlukan, pelatihan yang harus disertakan, sumber daya yang akan terlibat, dan kedudukan sistem manajemen Kinerja saat ini terhadap sistem manajemen kinerja yang baru. Pada saat penerapan, harus diuji apakah sistem manajemen kinerja tersebut telah dapat mengakomodasi 4 hal utama, yaitu pengukuran, evaluasi, diagnosis, dan tindak lanjut yang diperlukan jika kinerja perusahaan menyimpang dari standar yang telah ditetapkan.

e. Tahap 4 : Penyegaran

Merupakan langkah evaluasi terhadap kemutakhiran Sistem manajemen kinerja yang dirancang dengan mempertimbangkan informasi dan perkembangan pengetahuan terkini.

\subsection{Dashboard}

Berdasarkan ide yang didapat dengan mengadopsi instrument panel pada mobil, dimana panel tersebut dibuat untuk mempermudah pengemudi mobil untuk bisa mengetahui berapa kecepatan 
mobil, berapa putaran mesin, berapa jumlah bahan bakar yang ada, berapa suhu mesin dan panelpanel lain yang dapat menginformasikan kondisi mobil lainnya sehingga kita dapat mengontrol jalannya mobil kapanpun dan sesuai dengan yang kita inginkan. Dengan tujuan yang sama maka sistem panel kinerja (performance dashboard) versi digital dengan memanfaatkan teknologi komputer dibuat untuk membantu para bisnis atau proyek manager untuk mengontrol jalannya bisnis atau proyek.

Dashboard adalah alat bantu kontrol untuk mengidentifikasi jalannya proses bisnis secara mudah dengan menggunakan indikator-indikator tertentu seperti misalnya penggunaan indikator warna-warna khusus yaitu merah, hijau atau kuning yang melambangkan status atau kondisi dari suatu bisnis atau proyek, tanda peringatan, ringkasan-ringkasan, grafik-grafik seperti bar-chart, pie chart, dimana biasanya dibuat satu set dalam suatu portal, dan dapat diatur.

Performance Dashboard memiliki fungsi yang lebih dari hanya sekedar grafik-grafik performansi, performance dashboard adalah suatu bussines information sistem yang komplit yang dibangun dari bussines intelegent dan struktur data yang terintegrasi, dimana performance dashboard ini menampilkan mekanisme-mekanisme display dengan mudah.

Dashboard yang dibuat secara spesial dapat digunakan untuk mengontrol atau melacak semua bagian fungsional dalam suatu perusahaan, contohnya seperti untuk divisi human resource, recruiting, sales, operation, information technology (IT), project management, customer relation management (CRM) dan masih banyak lagi.

Istilah information dashboard didefinisikan sebagai tampilan visual dari informasi penting, yang diperlukan untuk mencapai satu atau beberapa tujuan, dengan mengkonsolidasikan dan mengatur informasi dalam satu layar (single screen), sehingga kinerja organisasi dapat dimonitor secara sekilas. Tampilan visual disini mengandung pengertian bahwa penyajian informasi harus dirancang sebaik mungkin, sehingga mata manusia dapat menangkap informasi secara cepat dan otak manusia dapat memahami maknanya secara benar (Few, 2006).

Tulang punggung dari sebuah dashboard adalah KPI (Key Performance Indicator). KPI menampilkan informasi berupa tabel, diagram, dan grafik. Untuk tiap level manajemen yang berbeda akan membutuhkan KPI yang berbeda pula untuk mendukung penilaian mengenai performansi/kinerja bisnis atau suatu proyek. Hasil penilaian KPI adalah pemunculan suatu indikator penting yang berpengaruh terhadap prestasi kinerja perusahaan dan dari indikator diharapkan diperoleh suatu nilai yang merupakan penyimpangan antara realisasi unit kerjanya dengan sasaran kinerja unit kerja tersebut. Gambaran umum sebuah Arsitektur sistem panel kinerja dapat dilihat pada gambar 1.

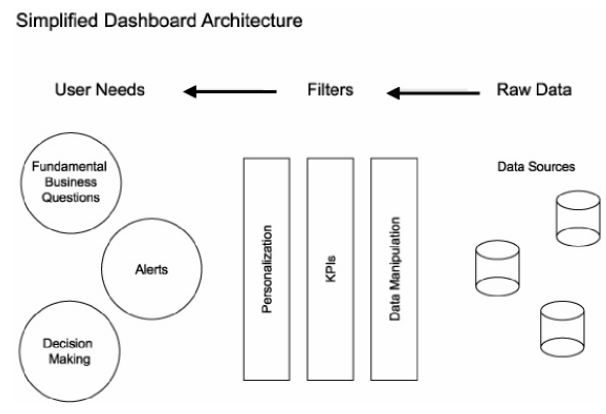

Gambar 1. Arsitektur Performance Dashboard (Kirtland, 2003)

\subsection{Key Performance Indicator ( KPI )}

KPI adalah seperangkat ukuran yang menitikberatkan pada aspek-aspek paling penting dari kinerja suatu unit kerja atau individu yang sangat berpengaruh terhadap prestasi unit kerja atau individu tersebut di masa kini maupun masa yang akan datang. Hasil penilaian KPI adalah pemunculan suatu indikator penting yang berpengaruh terhadap prestasi kinerja perusahaan dan dari indikator diharapkan diperoleh suatu nilai yang merupakan penyimpangan antara realisasi unit kerjanya dengan sasaran kinerja unit kerja tersebut. Penilaian kinerja berdasarkan KPI bertujuan untuk: 
a. Mengukur kesehatan dan kesejahteraan organisasi secara keseluruhan

b. Memfokuskan pada aspek atau area dari suatu kinerja organisasi yang kritikal dan vital secara berkelanjutan dan mengacu pada kesuksesan di masa yang akan datang

c. Mengukur suatu kesuksesan dalam area yang dianggap penting dan proses yang mempengaruhi customer, pekerja, shareholder dan stakeholder

d. Membangun total organisasi, individual departement dan individual team Sangat penting bagi sebuah perusahaan atau organisasi untuk paling tidak mengidentifikasi KPI nya.

\section{Metode Penelitian}

Peneliti memfokuskan metodologi pada tahap identifikasi kebutuhan, perencanaan dan perancangan prototype. Pembahasan dimulai dari prinsip pembangunan dashboard yang digunakan sebagai landasan dalam membuat metodologi. Prinsip pembangunan dashboard ini dirumuskan berdasarkan hasil kajian pustaka. Kerangka berpikir ini selanjutnya digunakan sebagai landasan dalam membuat metodologi pembangunan dashboard..

\subsection{Bahan Penelitian}

Bahan penelitian dalam penelitian ini adalah sebagai berikut:

a) Studi literatur

Tahapan studi literatur dilakukan untuk memperoleh landasan dan kerangka berpikir dari data yang mendukung penelitian ini disamping memberikan pemahaman mengenai berbagai teori pendukung dalam analisis dan pembahasan. Studi literatur ini menjadi acuan dalam penggunaan alat analisis, proses analisis dan penarikan kesimpulan. Studi pustaka yang dilakukan pada penelitian ini meliputi konsepkonsep pengukuran kinerja, Key Performance Indicator (KPI), dan Konsep Manajemen Kinerja serta instrumen evaluasi kinerja rumah sakit.

b) Jenis Data

Data yang dibutuhkan dan digunakan untuk penyelesaian masalah dalam penelitian ini adalah berupa data kuantitatif. Pengumpulan data tersebut dikumpulkan untuk mengidentifikasi dan menyusun Key Performance Indikator (KPI) sebagai dasar dari data untuk menyusun usulan dari desain model dashboard itu sendiri. Data yang diperlukan untuk menyusun desain model adalah sebagai berikut:

1. Data Primer, yaitu data yang diperoleh dengan survey dan wawancara dengan beberapa pihak di organisasi yang memiliki keterkaitan dengan permasalahan dalam peneltian ini.

2. Data sekunder, yaitu data yang telah tersedia dan diperoleh dari pustaka berkaitan dengan instrumen evaluasi kinerja rumah sakit.

\subsection{Alat Penelitian}

Alat yang digunakan untuk membuat sistem panel kinerja program studi sarjana adalah bersumber pada instrumen evaluai proses pembelajaran di perguruan tinggi. Sedangkan untuk membuat prototype aplikasi dashboard alat bantu komputer dengan sistem operasi WINDOWS, dan Microsoft Excel untuk Modeling.

\subsection{Metode Pengembangan Dashboard}

Metodologi pengembangan dashboard ini menggunakan pendekatan metodologi yang dikembangkan oleh vendor Pureshare. Metodologi ini dikembangkan oleh vendor PureShare untuk memfasilitasi proyek yang berhubungan dengan upaya pengukuran dan pengelolaan kinerja organisasi, termasuk didalamnya dalam pengembangan atau pembangunan dashboard. Proyek pembangunan dashboard dirancang agar selaras dengan tujuan bisnis dan kebutuhan teknologinya.

Gambaran umum dari kerangka metodologi yang dikembangkan oleh vendor PureShare dapat dilihat pada gambar 2 . 


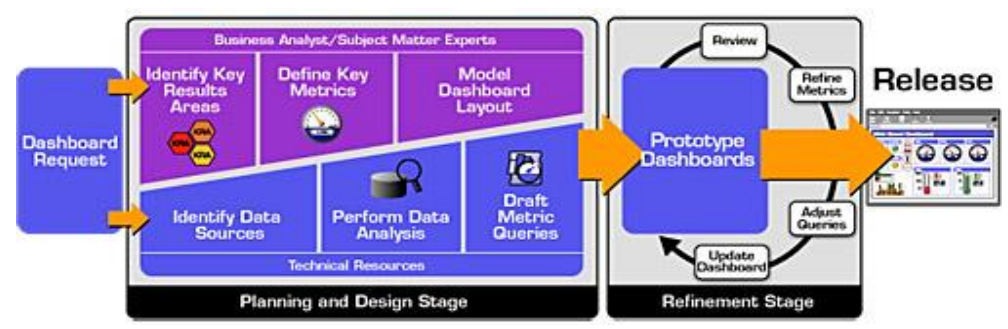

Gambar 2. Metodologi Pengembangan Dasboard PureShare

Metodologi yang dikembangkan oleh Pure Share memberikan penekanan pada kesesuaian antara tujuan bisnis dengan kebutuhan teknologi organisasi. Perancangan sistem dilakukan dengan pendekatan top-down yang memberikan fokus pada pemenuhan kebutuhan bisnis dan pengguna.

Pembuatan metodologi didasarkan pada kerangka berpikir yang telah dibahas sebelumnya. Dari kerangka berpikir tersebut, dapat diidentifikasi aktifitas-aktifitas yang diperlukan untuk pembangunan dashboard. Selanjutnya, aktifitas-aktifitas tersebut dihubungkan untuk melihat keterkaitan antara satu aktifitas dengan aktifitas lainnya. Keterhubungan antar aktifitas membentuk tahapan-tahapan, yang menjadi sebuah metodologi dalam pembangunan dashboard.

Metodologi pembangunan dashboard memiliki 7(tujuh) tahapan utama, sesuai dengan tahapan dalam pengembangan sistem perangkat lunak, yaitu identifikasi kebutuhan, perencanaan, perancangan prototype, review prototype, implementasi, deployment, dan maintenance. Pada penelitian ini hanya dibahas tiga tahapan yang pertama, yaitu identifikasi kebutuhan, perencanaan, dan perancangan prototype.

\section{Hasil dan Pembahasan}

Pada bagian ini akan dibahas mengenai hasil mengenai pembangunan dashboard untuk monitoring dan evaluasi pelaksanaan pembelajaran. Hasil dari penelitian ini diharapkan dapat digunakan untuk menunjang upaya penjaminan mutu dilingkungan Universitas Stikubank.

\subsection{Hasil Penelitian}

\subsubsection{Identifikasi Masalah}

Tahap ini mengidentifikasi permasalahan yang terjadi pada perancangan kinerja rumah sakit. Dari hasil identifikasi tersebut didapat bahwa permasalahan terletak pada belum adanya dashboard sebagai sistem monitoring dan evaluasi yang memberikan kemudahan bagi manajemen rumah sakit untuk melakukan monitoring kinerja dokter dan perawat dalam memberikan layanan kepada pasien.

\subsubsection{Pengumpulan dan Analisis Data}

Tujuan dari penelitian ini adalah untuk membuat model rancangan Dashboard untuk monitoring dan evaluasi pelaksanaan pembelajaran dengan memperhatikan 3(tiga) aspek utama yaitu data/informasi, personalisasi, dan kolaborasi. Ketiga aspek tersebut harus dimiliki oleh Dashboard, untuk memudahkan manajemen dalam memonitor pelaksanaan pembelajaran, sehingga diharapkan dapat digunakan untuk menunjang upaya penjaminan mutu pelaksanaan layanan kepada pasien. Data yang dibutuhkan dan digunakan untuk penyelesaian masalah dalam penelitian ini adalah berupa. Pengumpulan data tersebut dikumpulkan untuk mengidentifikasi dan menyusun key performance indikator (KPI) sebagai dasar dari pembentukan desain dashboard, dan data untuk menyusun usulan dari desain dashboard itu sendiri.

\subsection{Analisis Kebutuhan sistem}

\subsubsection{Identifikasi high-level scenario dashboard}

Tujuan pembangunan dashboard kinerja rumah sakit adalah untuk memonitor dan evaluasi layanan yang diberikan oleh rumah sakit kepada pasien terutama layanan dokter dan perawat. Monitoring dilakukan terhadap pelaksanaan layanan yang diberikan oleh dokter dan perawat. 


\subsubsection{Analisis Warna dan Meta-Informasi KPI}

Analisis meta-informasi dilakukan untuk menemukan elemen-elemen informasi yang menyertai setiap KPI seperti prioritas KPI, sumber data, granularitas, ukuran dan perhitungan, threshold, serta alert. Identifikasi elemen informasi yang menyertai setiap KPI disesuaikan dengan instrument dari layanan pasien di rumah sakit. Prioritas untuk setiap KPI ditentukan dengan menggunakan skala 15. Skala 1 menyatakan prioritas "Sangat Kurang", skala 2 menyatakan "Kurang", skala 3 menyatakan "Cukup", dan skala 4 menyatakan "Baik", serta skala 5 menyatakan "Sangat Baik". Penetapan rentang nilai menggunakan acuan sekala likert untuk mengukur tingkat kepuasan layanan, sedangkan untuk memberikan kemudahan pengguna informasi, alert ditampilkan dalam bentuk visualisasi warna. Tabel analisis warna dari masing-masing capaian standard mutu maupun indikator mutu dapat dilihat pada tabel 1 .

Tabel 1. Analisis Warna dan Meta-Informasi KPI

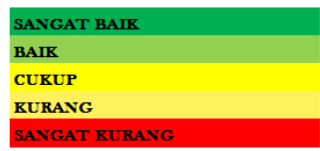

DIPERTAHANKAN

PERLU DI SEMPURNAKAN

BUTUH PERBAIKAN

BUTUH PERBAIKAN SEGERA

BUTUH PERHATIAN DAN PENGAWASAN KHUSUS

\subsection{Perancangan Prototype}

Perancangan Prototype dashboard adalah merancang antarmuka yang akan dihasilkan dalam visualisasi dasboard layanan pasien. Berdasarkan hasil pengidentifikasian indikator-indikator yang ada dan kebutuhan informasi dari pihak pengguna, maka dapat dirancang desain antarmuka dari dashboard sesuai dengan kebutuhan pengguna.

Dahsboard diawali dari data mentah yang berasal dari hasil penilaian kinerja layanan pasien yang dilakukan oleh pasien/keluarga pasien terhadap dokter dan perawat yang menangani pasien,yang kemudian akan disimpan kedalam database, selanjutnya akan dilakukan proses filterisasi, dimana proses ini ditujukan untuk melakukan manipulasi data dan personalisasi sesuai dengan kebutuhan inormasi, salanjutnya di visualisasikan dalam dashboard sesuai dengan kebutuhan masing-masing pengguna. Informasi dalam dashboard ditampilkan secara ringkas namun menyeluruh. Gambaran umum dari dashboard dapat di gambarkan ke dalam Arsitektur dashboard. Arsitektur tersebut dapat dilihat pada gambar 3 .

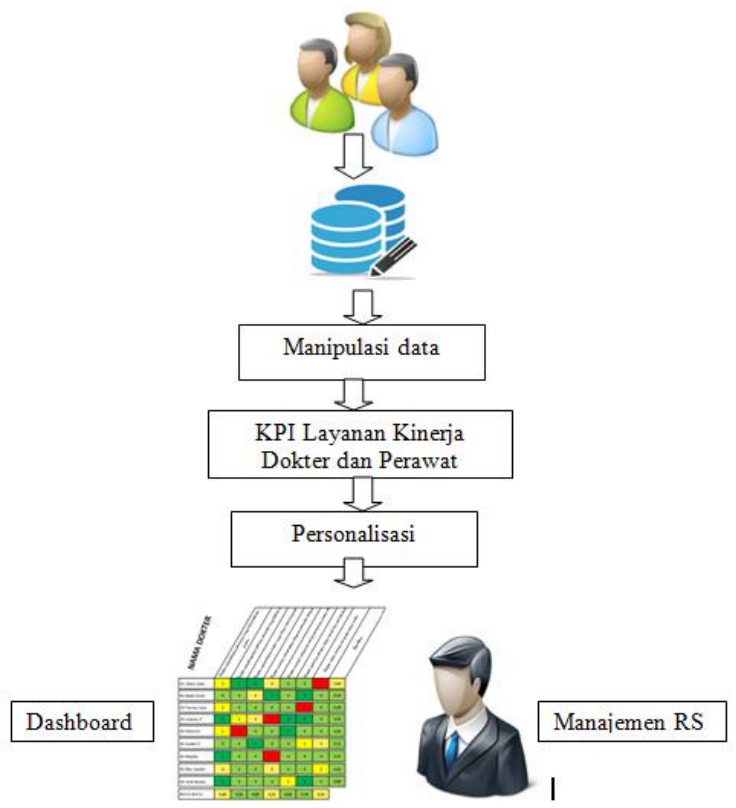

Gambar 3. Arsitektur Dashboard Kinerja Layanan Pasien Rumah Sakit 


\subsubsection{Rancangan Tampilan Dashboard Dokter}

Dalam rancangan dashboard ini merupakan informasi ringkas berkaitan hasil penilaian pelaksanaan kinerja layanan dokter kepada pasien ada. Manajemen rumah sakit bisa melihat dengan mudah dam jelas kelebihan dan kekurangan masing-masing dokter dalam memberikan layanan kepada pasien pada indikator-indikator yang ada. Hasil Tampilan halaman utama dapat dilihat pada gambar 4.
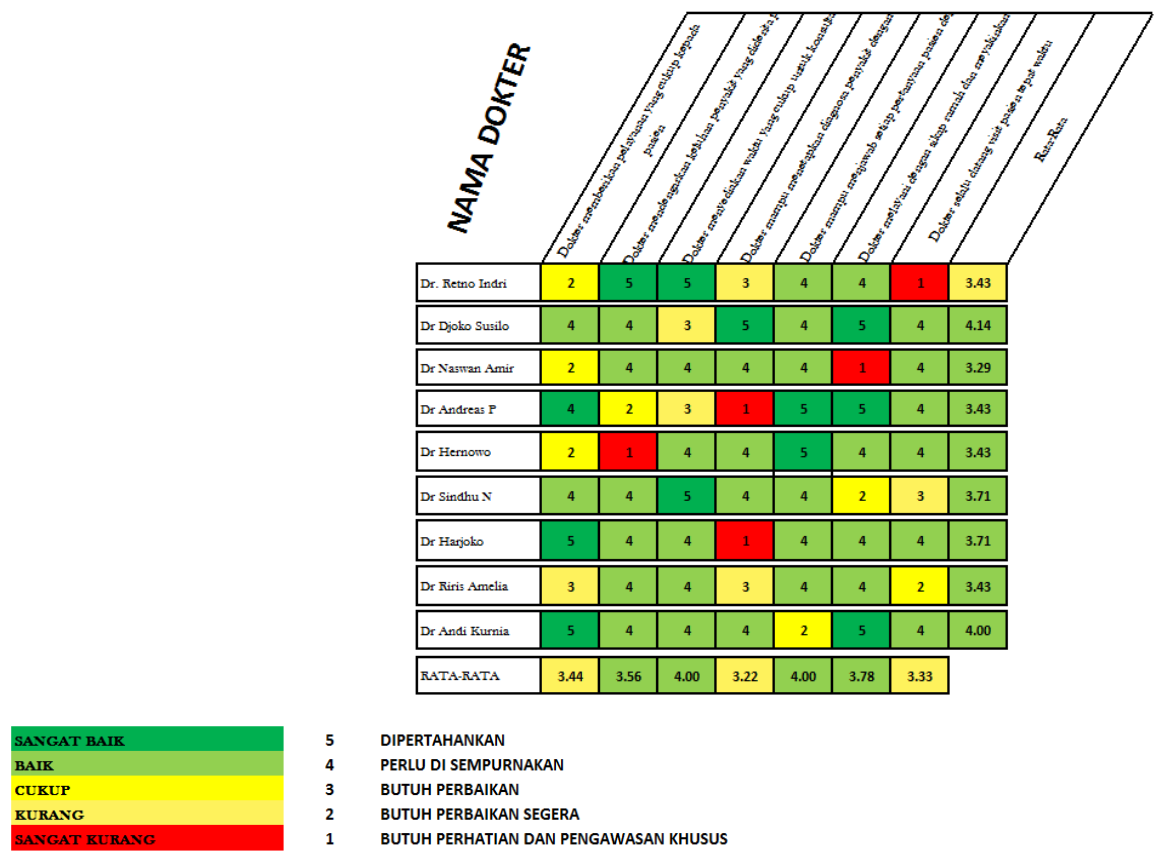

DIPERTAHANKAN

PERLU DI SEMPURNAKAN

BUTUH PERBAIKAN

BUTUH PERBAIKAN SEGERA

BUTUH PERHATIAN DAN PENGAWASAN KHUSUS

Gambar 4. Rancangan Dashboard Kinerja layanan Dokter

\subsubsection{Rancangan Tampilan Dashboard Perawat}

Dalam rancangan dashboard ini merupakan informasi ringkas berkaitan hasil penilaian pelaksanaan kinerja layanan perawat kepada pasien ada. Manajemen rumah sakit bisa melihat dengan mudah dam jelas kelebihan dan kekurangan masing-masing pasien dalam memberikan layanan kepada pasien pada indikator-indikator yang ada. Hasil Tampilan halaman utama dapat dilihat pada gambar 5.
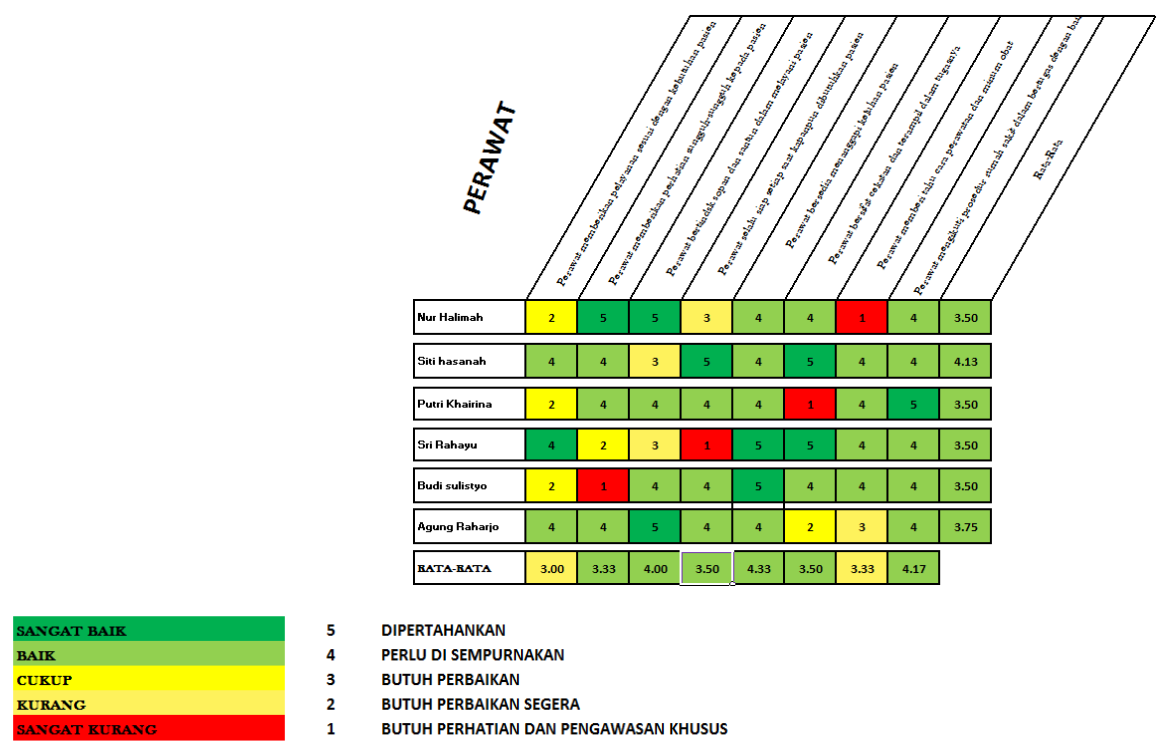

DIPERTAHANKAN

PERLU DI SEMPURNAKAN

BUTUH PERBAIKAN

BUTUH PERBAIKAN SEGERA
BUTUH PERHATIAN DAN PENGAWASAN KHUSUS

Gambar 5. Rancangan Dashboard Kinerja layanan perawat 


\section{Kesimpulan dan Saran}

\subsection{Kesimpulan}

Kesimpulan yang dapat diambil dari penelitian yang telah dilakukan adalah:

a. Dashboard untuk kinerja layanan pasien ini menggunakan indikator kepuasan layanan pasien terhadap layanan dokter dan perawat, dengan cara tersebut setidak-tidaknya akan memberikan gambaran yang jelas dari waktu ke waktu kepada manajemen rumah sakit berkaitan dengan pencapaian kinerja dokter dan perawat dalam pelaksanaan medis.

b. Data yang digunakan memiliki frekuensi harian. Dapat dikatakan bahwa data yang digunakan tersebut real time, sehingga perubahan nilai-nilai indikator pada dashboard bisa dimonitor setiap waktu. Sehingga monitoring dan evaluasi dokter bisa dilakukan setiap saat.

c. Kinerja untuk layanan pasien terkait dengan kinerja layanan rumah sakit secara keseluruhan belum tercakup dalam penelitian ini.

\subsection{Saran}

Dari pelaksanaan penelitian ini dapat diambil beberapa saran sebagai berikut:

a. Pengembangan aplikasi dashboard yang digunakan dalam penelitian ini hanya sampai pada pembuatan aplikasi prototype, untuk itu pelu diusulkan untuk ditindak lanjuti untuk implementasi, deployment, dan maintenance.

b. Untuk penelitian di masa yang akan datang Perlu untuk dilakukan tindak lanjut untuk mengembangkan dashboard kinerja layanan rumah sakit yang mencakup semua aspek penilaian yang ada pada rumah sakit.

\section{DAFTAR PUSTAKA}

[1] Cooper, D.R. , Emory, C.W., 1996. Metode Penelitian Bisnis, Erlangga.

[2] Eckerson, W., 2005. Deploying Dashboard and Scorecards, TDWI Best Practices Report.

[3] Eckerson, W., 2006. Performance Dashboards: Measuring, Monitoring, and Managing Your Business.New Jersey:John Wiley \& Sons.

[4] Few, S., 2006. Information Dashboard Design, O’Reilly; ISBN: 0-596-10016-7.

[5] Golfarrelli, M. 2005. New Trends in Business Intelligence. Proceedings of the 1st International Symposium on Business Intelligent Systems, Opatija, Croatia, 15-26.

[6] Gonzales, Tom. 2006, Dashboard Design: Key Performance Indicators \& Metrics - Choosing the Right Data to Display, BrightPoint Consulting, Inc.

[7] Gregory S, Nelson. 2010. The Healthcare Performance Dashboad: Linking Strategy to Metrics. SAS Global Forum 2010. Thotwave Technologiws, Chapel Hill, North Carolina.

[8] Harel, E.C., Sitko, T.D., 2003. Buletin Center For Applied Research, Volume 2003, issue 19, September 16, 2003.

[9] Malik, Shadan. 2005. Enterprise Dashboards - Design and Best Practices for IT. John Wiley \& Sons, Inc.

[10] Mettler, Tobias; \& Vimarlund, Vivian.. 2008. Understanding Business Intelligence in the Context of Helath Care, Proceedings of the $13^{\text {th }}$ International Symposium on Health Information Management Research - ISHIMR.

[11] Mihaela I.Muntean, Diana-Alexandra Tarnaveanu, dan Anca Paul. BI Approach for Business Performance. Proceedings of the 5th WSEAS International on Economy and Management Trasformation (Volume II)

[12] Starmer, John; \& Giuse, Dario. 2008, A Real-time Ventilator Management Dashboard: Toward Hardwiring Comliance with Evidence-based Guidelines. AMIA 2008 Symposium Proceedings. Vanderbilt University Medical Center, Nashville,TN.

[13] Wibisono, P.h.D, Dermawan, 2006, Manajemen Kinerja: Konsep Desain dan Teknik Meningkatkan Daya Saing Perusahaan, Bandung, Erlangga. 